Historic, Archive Document

Do not assume content reflects current scientific knowledge, policies, or practices. 



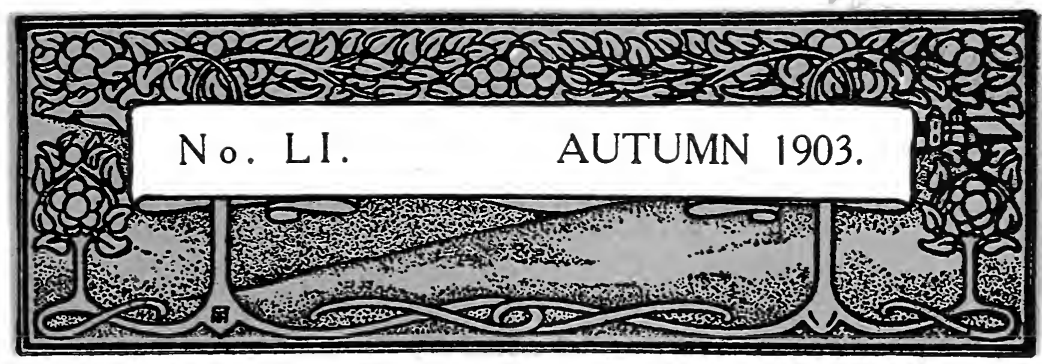

SPECIALTIES

Choice Hardy

Trees, Shrubs

* Roses *

Herbaceous Plants

Bulbs, Etc., Etc

\section{FALL PLANTING}

FRED'K W. KELSEY

150 Broadway, New York City

Cable Address: Kellenwood New York 


$$
\text { • }
$$




\section{Autumn 1903.}

\section{Preface.}

THIS ABRIDGED CATALOGUE includes only a partial list of the finer Trees and Hardy Plants; Street Trees; collections of the best Shrubs, Roses, the finest hardy Azaleas, Rhododendrons; trained Fruit Trees; Foreign Grape Vines, etc. For more complete lists, descriptions, etc., see General Catalogue Nio. 50, for 1903.

THE NURSERY BUSINESS is rapidly growing in importance, and under my present methods of selection and distribution, the best stock in this country and abroad is furnished in far greater variety than is possible in "picking out" the material in any one Nursery or from several Nurseries. With my system of direct importations from carefully selected stock in the leading Nurseries in Europe, and contracts for growing and special selection with a great many of the best growers of hardy stock in this country, almost every variety of trees and hardy plants of reliable quality and condition is furnished at LOWEST CURRENT PRICES, and on large lists.

THE QUALITY of all stock is of first consideration. Much care is exercised in having all material properly grown and transplanted, and the digging and packing done under the most approved methods to insure, in both long and short distance shipments, the arrival of the stock in perfect condition.

SAMPLES provide an efficient and inexpensive way of judging of the quality and value of stock, and where furnished with the customary proposal are more reliable than the much more costly methods of looking over the same material in nursery rows. Samples are submitted or inspection invited where there is question as to the quality of stock desired.

Specialties. Street, Avenue and Lawy Trees; Japanese Maples; specimen Evergreens, many times transplanted and moved with ball; Trained Trees for Formal Gardexs; the finest HARDY Azaleas, and the strictly reliable "iron-clad hardy" Rhododendross-beautiful plants with buds for immediate effect; special collections of the best hardy Deciduous Shrubs; the finest Standard Shrubs; Hedge Plaxts, all sizes and varieties; special collections of the best hardy Roses; Rosa Rugosa; hardy Herbaceous Plants; hardy Bulbs; Trained Fruit Trees for fruit house and gardens; Foreign Grape Vines; and the best grade of Grass Seed.

SHIPMENTS are made when the stock is in best condition for removal, usually during Narch and April in spring; October and November in autumn.

PRICES are of F. O. B. New York, and stock is forwarded under the low Trunk Line classification rates; or if by express at 20 discount from schedule express rates. On stock furnished at special net prices and in carload lots, freight charges follow from point of shipment. PACkisG-There is no charge for labor and cost of packing excepting the customary charge of the actual cost of boxes or bales necessary in protecting the stock in the best possible condition.

AUTUMN PLANTING. Fall planting in many places is desirable. There is more time to do the work properly. The tree or shrub is in condition for immediate growth in spring. Nearly all deciduous trees and shrubs can be advantageously shipped and transplanted in autumn; also JAPaxese Maples, Rhododendrons and hardy Azaleas, Lilies, Herbaceous Playts, and hardy Roses in the open ground, EvergreENs as a rule are better moved in the spring.

LANDSCAPE PLANS. In the proper treatment of all ornamental grounds carefully considered landscape plans are as important as are architects' plans in building construction; and grievous mistakes-costly to remedy in future-are thus not infrequently aroided. The best results usually obtain where competent men are employed for this work. While conversant with the best examples of landscape treatment in this country and in Europe, no pretense is made of being a Landscape Architect; but I am always glad to advise regarding competent specialists for this work and these improvements, without charge, and when desired arrange for landscape work with the furnishing of requisite planting material at reasonable cost.

GARDENERS' POSITIONS. I have always on my books a list of competent head-gardeners and assistant gardeners, such as can be recommended as reliable and trustworthy for filling these positions satisfactorily. There is no charge for registering or for this service; the pleasure or satisfaction from a country estate depending as it does so largely upon loyal, competent service in the gardening department.

\section{FRED'K W. KELSEY. 150 Broadway, New York.}




\section{Deciduous Shade Trees.}

The followisg are a few of the desirable Ornamental and Shade Trees I am furnishing this season, of exceptional value for the sizes and grades offered.

All are nursery grown and properly transplanted. Extra sizes of many varieties can be supplied in quantity; also small sizes per thousand, for transplanting, at special low prices. Particulars on application. For more complete list of varieties and description, see Catalogue No. 50, for 1903 .

AILANTHUS glandulosa. A rapid-growing hardy tree. Long pinnate foliage; valuable for tropical effects. 50 cts. to $\$ I$.

ALDER, European. Alnus Glutinosa. Very rapid grower. $35 \mathrm{cts}$. to $\$ \mathrm{I} ; \$ 20$ to $\$ 50$ per 100 . Smaller, \$5o to \$IOo per I, ooo.

ALDER, Imperial Cut=leaved. Deeply cut leaves. Fine for the lawn. \$I to \$I.50. Low rates per Ioo.

AMELANCHIER Botryapium. The American JUNE BERRY or SHAD BLOw. Beautiful white flowers in April, followed by purplish fruit in June. 50 cts. ; $\$ 3$ to $\$ 5$ per dozen.

ASH, American White. 25 cts. to \$I.75.

ASH, Aucuba=leaved. Fraxinus Aucubafolia. Gold-blotched leaves. Effective in contrast. 50 cts. to $\$ 1.50$.

ASH, Gold=barked. F, Aurka. Yellow bark; fine. \$I.

BAY TREeS. See Sweet Bay Trees, page 9.

BEECH, European. Fagus Sylvatica. Makes a good hedge. $\$ 25$ to $\$ 50$ per Ioo. Smaller \$50, $\$ 75$ and $\$$ IOO, and upwards, per I, ooo.

BEECH, Fern=leaved. F, Heterophylla. Beautiful foliage. $\$ \mathrm{I}$ to $\$ 2$.

BEECH, Purple=leaved. F. Purpurea. The darkest purple. $75 \mathrm{cts}$. to $\$ 1.50$ each; $\$ 40$ to $\$$ Ioo per ioo. Smaller, \$25 per ico.

BEECH, Weeping. Fagus Pendula. Three to four feet and upwards, $75 \mathrm{cts}$. to \$2.50 each. Smaller trees, \$50 per Ioo.

BIRCH, Cut=leaved Weeping. Fine cut foliage. White bark. $75 \mathrm{cts}$. to $\$ 5$ each.

BIRCH, European White Weeping. BETUlA Alba. Very low rates per ıoo and I,ooo. All sizes.

BIRCH, Paper or Canoe Birch. B. Papyracea. Low rates in quantity for all sizes.

BUTTERNUT. Juglans Cinerea. A fine native tree; attains large size; Ailanthus-like foliage. 5o and $75 \mathrm{cts} ; \$ 3$ to $\$ 6$ per dozen.

CATALPA Bungei. Standards ; straight stems ; compact, round heads; large, glossy foliage. Fine for formal planting. \$I5 to \$25 per dozen.

Catalpa, Golden. Catalpa Aurea Variegata. \$I each; \$9 per dozen.

CATALPA, Speciosa. Very hardy; rapid growth. Very desirable, and largely used for street and avenue planting. \$IO to $\$ 50$ per Ioo. Low rates per $\mathrm{IOO}$ and per $\mathrm{I}, \mathrm{OoO}$.

CATALPA. Syringærolia. The common Catalpa indigenous in the South. \$4 to \$6 per dozen. Low rates per 100 .
CELTIS or Nettle Tree. A fine native small tree; light shiny green foliage. \$4 to \$6 per dozen.

CHERRY, Double Flowering. CERASUS ALBA PLENA. A mass of beautiful white flowers in May. 50 cts. to $\$ I$.

CHERRY, Japan Weeping Roseflowering. C. Rosea Pendula. New Japanese variety; double rose-colored flowers. One of the finest small ornamental trees. Pendulous habit. A perfect mass of rose-colored flowers, very early in spring. \$I5 and \$2O per dozen.

CHESTNUT American. Castainea Americana. Fine trees of all sizes. \$25 to $\$ 75$ per Ioo.

CHESTNUT, Paragon. Sweet fruit, much larger than our common American Chestnut. Comes into bearing soon after transplanting. \$I to \$2.

CHESTNUT, Spanish. C. Vesca. Large nuts, of fine quality. $\$ 4$ to $\$ 6$ per dozen.

CRAB APPLE, Bechtel's Flowering. Pyrus Angustifolia. A beautiful flowering tree, BLosSOMS LIKE SMALL ROSES in great profusion in early spring. New and rare. \$Io and \$I5 per dozen.

CRAB APPLE, Parkman's Flowering. P. HALLEANA. Masses of beautiful carmine flowers in spring: rich glossy foliage. Very fine. \$6 to \$Io per dozen.

DOGWOOD, White=flowering. CORNUS FLORIDA. 35 cts. to $\$$ r. 50 each. Special prices in quantity.

ELM, American. Uluus Americana. Fine stock. All sizes up to 4-inch caliper. Prices per Ioo and I, ooo on application.

ELM, Camperdown Weeping. Two or three years' head; fine. \$Io and \$ I5 per dozen. Low rates per IOC.

ELM, English. U. Campestris. Different sizes. $\$ 30$ to $\$ 75$ per Ioo; 4 to 6 feet, \$Io per IOo; $\$ 75$ per I, OOO.

ELM, Huntingdon, Superba, Scotch, Dovæi. Good trees for street or park planting. 50 cts. to $\$ 1.50 ; \$ 25$ to $\$ 75$ per Ioo.

HORSE CHESTNUT, Red=flowering. AsCULUS Rubicunda. Fine. \$I to \$2. A few fine specimens.

HORSE CHESTNUT, White. A. HIPPOCASTANUM. 50 cts. to \$I. Prices in quantity on application.

HORNBEAM. CARPINUS. A fine tree. Also used for hedges. \$20 and \$30 per roo.

HONEY L'CUST. Gleditschia. Beautiful foliage, large sharp thorns. A fine tree. Also desirable hedge plant for defensive planting. Low rates in quantity. 


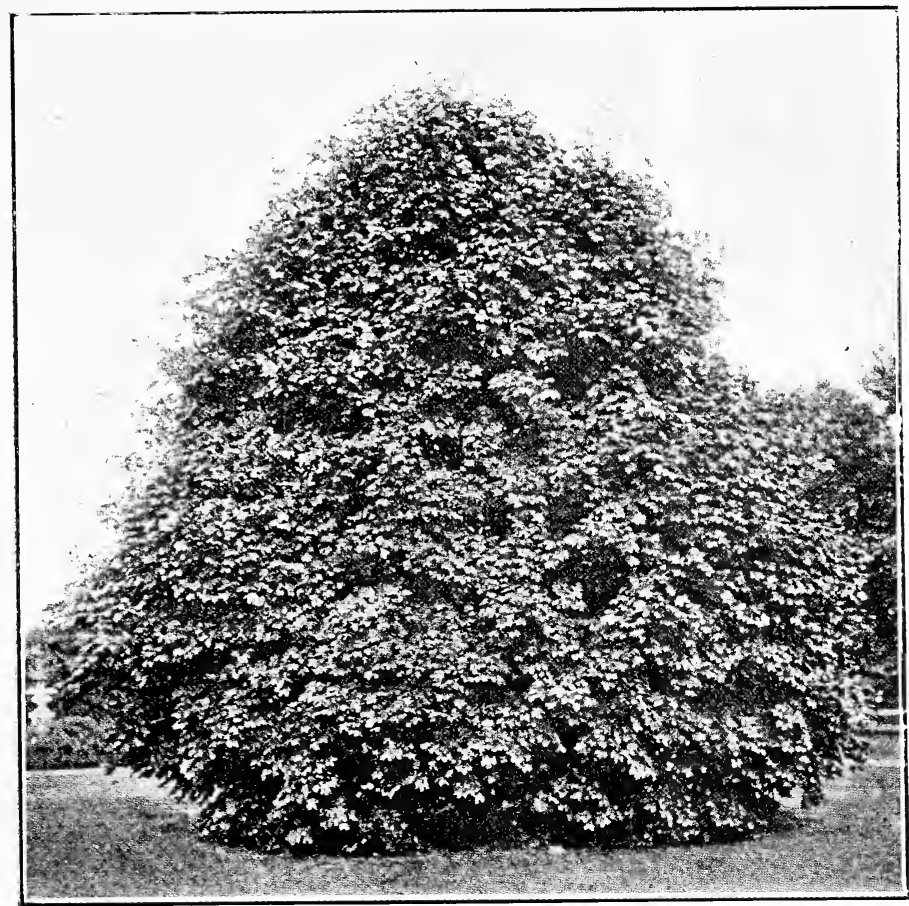

SCHWEULF, 'S MAPLE.

JUdAS TREE. Cercis Canadensis. Per Ioo and $\mathrm{I}$, oco at low rates.

JUDAS TREE, Japan. C. JAPONICA. One of the finest dwarf flowering trees. \$20 to $\$ 40$ per roo.

LARCH, American. Larix Americana. Fine seedlings. 2 to 5 feet. $\$ 25$ to $\$ 50$ per $\mathrm{I}, \mathrm{ooO}$.

LARCH, European. I. Europea. Fine transplanted trees of this beautiful tree. $\$ 20$ to $\$ 35$ per IOO.

LABURNUM or Golden Chain. Cytissus LABURNUM. Fine trees. \$20 to \$40 per 100 .

LIQUidambar Liquidamber Styraciflua. The Native SweEt Gum tree. Beautiful starshaped leaves, turning a vivid crimson in autumn. $\$ 5$ and $\$ 7.50$ per dozen." Special per IoO.

LINDEN, American. Tilia Americana. All sizes for street planting. $\$ 25$ to $\$ 75$ per roo. A limited number of large specimens.

LINDEN, European. T. Europæa. Fine trees; different sizes, at low rates in quantity.

LINDEN, White=Leaved. T. Alba. Dark green foliage, clear white underneath. Fine. \$5 to \$ro per dozen.

MAPLE, Ash=leaved or Box Fider. ACER NEguNDo. Fine trees. \$I5 to \$25 per roo. Special prices in quantity.

MAPLE, Japanese. A. JAPONICA. The best specimens and collections of very fine plants. All the hardiest and best red and crimson= leaved varieties - Atropurpureum, Sanguine= um, Rubrum, Ornatum; $\mathbf{N i}=$ grum, Palmatum, etc.-and choice new kinds. Different sizes, $\$$ I to $\$ 2.50$ each. Case collections of the best plants for grouping or planting in beds, 25 and 50 plants per case, $\$ 30$ to $\$ 100$ per case, according to size. For varieties, descriptions, etc, see Catalogue No. 50, pages 6 and 7 .

MAPLE, New Purple=leaved. A. Platanoides atropurPUREA. Foliage and leaf stalks a distinct maroon red and REDDISH PURPLE COLOR in midsummer. Very fine and hardy. $\$ 1$ to $\$ 2$ each, $\$ 10$ to $\$ 20$ per dozen.

MAPLE, Norway. A. PlataNoIDEs. The best street tree. All sizes, up to 4-inch caliper, at low rates. $\$ 25$ to $\$ 500$ per roo. Special prices for different sizes on application.

MAPLE, Reitenbachii. Fine crimson. \$I to \$2.

MAPLE, Scarlet. A. Rubrum. $\$ 6$ and $\$ 8$ per dozen. 3 to 5 feet, \$ro per roo.

MAPLE, Schwedlerii. Leaves red or crimson; very fine, $\$ \mathbf{I}$. Low rates per 100 .

MAPLE, Silve r=leaved. A. Dasycarpum. Extra sizes, $\$ 30$ to $\$ 50$ per roo. Smaller, \$Io to $\$ 25$ per IOo; low rates per I, Ooo.

MAPLE, Sugar. A. Saccharinum. All sizes, up to 3 -inch caliper. $\$ 25$ to $\$ 400$ per roo.

MAPLE, Sycamore. A. Pseudo-platanus. All sizes at low rates in quantity.

MAPLE, Wier's Cut=leaved. A. WIERI LACINIATum. Delicately cut leaves, graceful habit. 50 to $75 \mathrm{cts}$. ; low rates per Ioo.

MOUNTAIN ASH. Pyrus or Sorbus. Fine trees, of EUROPEAN, OAK-LEAVED and WEEPING varieties. Different, sizes, from \$Io per IoO upwards.

MULBERRY, Downing's White, Russlan, and other varieties. Good stock of different sizes. $\$ 15$ to $\$+O$ per roo.

MULBERRY, Weeping. Morus Pendula. Of perfect umbrella form. \$I and \$I.50.

OAK, American Whire, Burr or Mossy Cup Oak, Chestnut Oak, Willow=leaved Oak, Pin Uak, Q. Palustrus, Pyramidal Oak, English, Red, Q. Rubra, Scarlet, Turkey, Q. CERris, and other varieties in small sizes at reasonable prices.

OAK, Golden. Quercus aurea. One of the most beautiful colored foliage trees. Thick bright golden foliage. \$I to $\$ 2$.

OAK, Purple. Q. Atropurpurea. Dark, rich colored purple leaves. \$2.

POPLAR, Bolleana. Resembles Lombardy. Similar, compact, upright grewth. Glossy green folisge, silver white underneath. Fire. $\$ 4$ to $\$ 6$ per dozen. 
POPLAR, Carolina. Populus. Rapid growth, large foliage, hardy transplants easily in almost any soil or location. Largely used for street planting where immediate effect is desired. Fine stock, 4 to 6 feet up to is or 20 feet, at very low rates; per Ioo and I, ooo. \$ro per Ioo and upwards. Special prices for all sizes in quantity on application.

POPLAR, Lombardy. P. Fastigiata. The upright growing variety, very fine for landscape effects, and as background for other plantings. $\$ 3$ to $\$ 6$ per dozen. Special prices on application.

PAULOWNIA. Rapid growth, immense leaves, fine for tropical effects. \$9 per dozen.

PLATANUS. The Plane tree. Fine for street planting. \$6 to \$ro per dozen. A limited number of large sizes.

SALISBURIA or Maiden Hair. SALISBURIA ADIAxtifolia. Fine fanlike foliage, rare. \$Io per dozen.
THORN, Cockspur Thorn. C'Rategus CRUsGALLI. $\$ 3$ to $\$ 5$ per dozen. Low rates per roo.

THORN, Double Red, Scarlet, White. C. jo and 75 cts. Low rates per Ioo.

THORN, Hawthorn. C. OxYcantha. $\$ 3$ to $\$ 5$ per dozen. Fine hedge plant $\$ 5$ to $\$$ io per IOO.

WALNUT. Juglans Nigra. The well known Black Walnut, 50 cts, ; \$20 to \$fo per Ioo.

WALNUT, Japan. J. Japoxica. A desirable novelty. Nuts produced in c usters of $I_{5}$ to 20 on a stem; very large size. Flavor sweet, like butternut; fine quality Tree hardy and productive. Si to $\$ 2 ;$ SIO to $\$ 20$ per dozen.

Willow, Common Weeping. Salix BabyloxicA. Fine trees. 50 cts. each; $\$ I_{5}$ to $\$ 40$ per IOO.

WILLOW, Laurel = leaved. S. LAURIFOLIA. Shining, rich leaves; rapid growth. $\$ 3$ to $\$ 5$ per dozen. Low rates per ioo.

\section{TREES OF LARGE SIZE FOR IMMEDIATE EFFECT.}

Maples, Elms, Lindens, Horse Chestnuts, Planes. Poplars and most deciduous trees can be put out with perfect safety in autumn. Silver-leaved or soft Maples, Magnolias and Tulip Trees are, however, better in spring.

As a rule, the medinm sires of these larger trees are preferable; those Io to I 2 . I 2 to I 5 , or I5 to I 8 feet making better specimens after a few years than the extra large sizes.

Prices and particulars on application for large trees of the foll: wing, of different sizes:

\begin{tabular}{|c|c|}
\hline $\begin{array}{l}\text { American Elm, } \\
\text { Ash=leaved Maple, } \\
\text { Carolina Poplar, } \\
\text { Catalpa. }\end{array}$ & $\begin{array}{l}\text { European Ash, } \\
\text { European Linden, } \\
\text { Lombardy Poplar, } \\
\text { Norway Maple, }\end{array}$ \\
\hline
\end{tabular}

Silver=leaved Maple,

Sugar Maple,

Weir's Cut=leaved Maple,

White Birch,

Cut=leaved Birch,

Oriental Plane,

White=flowering Horse Chestnut.

Smaller sizes of the above and others at lowest rates per Ioo and I,ooo. Particulars and prices on application.

NATIVE TREES write for list and particulars of best native varieties at low prices.

\section{Young'

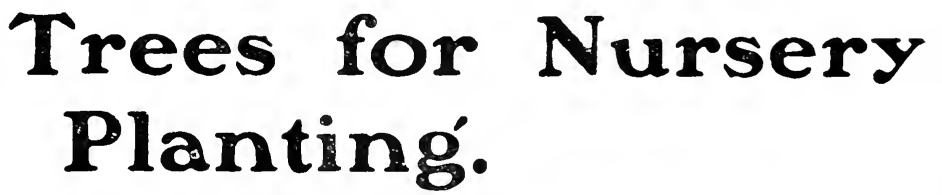

For parks and all other public institutions or private estates, where future planting is required, these small trees are very desirable in point of economy; largely increasing in value every year.

From 4 ,ooo to 6, ooo can be advantageously planted per acre, with the rows + to 6 feet apart.

\section{YOUNG DECIDUOUS TREES.}

The following are the varieties recommended for this purpose, which I supply in nice transplanted stock of different sizes, at the low net prices quoted:
Beech,
Birch,
Common Ash,
Hornbeam,

\section{Elms, \\ Lindens, \\ Mountain Ash, Maples,}

\section{Willows.}

Oaks,

Poplars,

Sycamore or Plane,

White Horse Chestnut.

Prices: 2 to 4 and 4 to 6 feet, $\$ 50, \$ 75$ and $\$$ ioo per $\mathrm{I}, 000$. 


\section{SMALL EVERGREEN TREES.}

Good transplanted stock of the following and other varieties can be supplied by the roo or I,ooo, and smaller sizes of such as the Arbor Vites, Austrian Pine, Norway Spruce, Scotch Fir, Scotch Pine, White Pr:se, etc., by the io,ooo on specially favorable terms.

Prices for the following kinds, I 2 to IS, IS to 24 , and $2+$ to 30 inches, $\$+0, \$ 60, \$ 75$ and $\$$ Ioo per I, ooo net, according to size and variety:

\section{American Arbor Vitæ, Siberian Arbor Vitæ, Austrian Pine,}

White Pine, Mountain Pine, Douglas Spruce,

\author{
Hemlock Spruce, \\ Norway spruce, \\ White Spruce,
}

\author{
Scotch Fir, \\ Trailing Juniper, \\ English Yew.
}

\section{Choice \\ Hardy

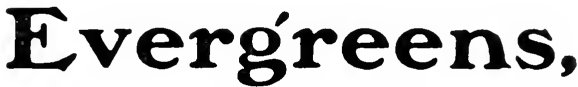

Of the following rare and choice kinds, as also for the common Arbor VITÆs, SprUCEs, etc., I can make very favorable prices for fine transplanted, well-rooted, well-furnished stock, both in fine specimens and in quantity per Ioo and per I,ooo. Orders booked for shipment now or at proper time in spring. Most evergreens succeed best transplanted in spring.

For more complete list of Evergreens, description, etc., and list of Choice Evergreens in Trained Specimens, see full catalogue, No. 50, for 1903.

ARBOR VIT $\boldsymbol{A}$, American, Siberian. Fine hedge plants, of different sizes. I 2 to IS inches up to 5 and 6 feet; special low prices per Ioo and I,ooo. \$5 and upwards per Ioo.

CEDRUS Atlantica Glauca. New and very choice; medium size, compact growth; fine, delicate leaves of a most beautiful glaucous steel-blue tint; color equal to the finest of the Colorado Blue Spruce. Has proved hardy at Newport. \$2.50 to \$5 each.

CEDRUS, Cedar of Lebanon. Cedrus Libani. Vigorous spreading branches, with large, dark green foliage; young growth tender. Choice, $\$ 1$ to $\$ 2$ each. Low rates per \$IOO.

CEDRUS, Deodar Cedar. C. Deodara. Graceful foliage of a light silvery or glaucous-green. One of the most beautiful and satisfactory Evergreens; not entirely hardy north of Philadelphia. \$I to \$2 each. Low rates per Ioo.

HEMLOCK. Abies Canadensis. Very fine hedge plants. I2 to Is inches up to 4 and 5 feet; at low rates per Ioo and I, ooo on application.

JUNIPER, Golden. J. Aurea Prostrata. Spreading Golden Juniper. Hardy and fine. I 2 to IS inches high, by 2 to 3 feet diameter. Sio to Si5 per dozen.

JUNIPER, Trailing. J. Prostrata. A very hardy variety. Adapted to almost any soil or location. Low-spreading habit, rich foliage. Fine for massing or rock work. Well-furnished, well-rooted plants in quantity at low rates. Particulars on application.

PINe, Austrian, Scotch, White. Good transplanted stock of these leading hardy varieties. Extra, 5o cts. to SI each: S Io to $\$ 25$ per Ioo. Smaller, $\$ 25$ to $\$ 75$ per $\mathrm{I}, \mathrm{Ooo}$. Prices and particulars on application.

RETINOSPORA. Good specimens of Filifera, Golden, Plumosa, Pisifera and Squarosa. 75 cts. to $\$ 1.50$ each. Finc plants, Is to 24 inches and 2 to 3 feet and upwards, $\$ 25$ to $\$ 50$ per IoO.

SCIADOPITYS Verticillata. UMbrella Pine. A very odd and unique tree. Longer leaves than those on other Coniferæ, shining green above and a line of white underneath. The horizontal branches and peculiar growth of the leaves in parasol-like whorls gives this variety a very distinct individuality. $\$ 2$ and $\$ 3$ each. A few extra specimens, specially grown in baskets, up to 8 or 9 feet. Prices on application.

SILVER FIR. PICEA. Concolor. The finest of the Rocky Mountain Firs. I to 2 feet and 2 to 3 feet. Nice transplanted stock, \$+o, \$75 and $\$$ Ioo per Ioo. Extra specimens, \$2.50 to $\$ 5$ each.

SILVER FIR, Cephalonian, Siberian, Silician, Nordmanniana. Fine young specimens of all these choice varieties, \$I. 50 to $\$ 2.50$, according to size. Low rates per Ioo for young transplanted stock, I to 3 feet.

SPRUCE, Colorado Blue. Picen Pungens. The "true blues" of this variety are generally admitted to be the most strikingly beautiful of all the hardy Coniferæ. The trees are easily grown, transplant successfully, and are hardy everywhere; the steel-blue color that gives this variety its peculiar charm is still rare. Always a marked object in lawns or landscape. Fine, transplanted specimen trees of the real blue color, IS inches to 6 or $S$ feet, \$I. 50 to $\$$ I 25 each. Seedlings, not selecte 1 color, at low rates per roo. Prices and particulars on application.

SPRUCE, Douglas. Good transplanted stock of this valuable tree, I to 2 and 2 to 3 feet, $\$ I_{5}$ to \$30 per IOO.

SPRUCE, Norway. Fine specimens; all sizes from Is to $2+$ inches to 6 feet and larger at low rates per Ioo. Nice transplanted, small sizes, for hedges, at special low prices per I,ooo.

YEW. Taxus. Golden, English, Erect, Irish, and others. $50 \mathrm{cts}$. to SI each. Low rates per Ioo. Fine specimens of English Yew 2 to 3 feet broad at base and 5 feet high, and of the Irish Yew 2 to 3 feet broad and 0 feet high, several times transplanted. Particulars on request. See also Trained Specimens for ForMAL Gardens, General Catalogue No. 50, for I903.

All the plants arrived in good order and now appear to be doing well. I enclose my check to your order for amount of enclosed invoice. \$75.75.

Providence, R. I.

H. G. R. 


\section{Fine Hardy Shrubs.}

Particular Attention is called to the Special Collection of Shrubs, on page 9; also to the following complete assortment, including Evergreen Shrubs, all of which are now offered at very low prices for first-grade stock.

Small Sizes for transplanting can be supplied at special prices per roo and r,ooo. Particulars on application.

Of Trained Specimens for formal gardening, many desirable trimmed Evergreens and Deciduous Shrubs can be supplied at reasonable prices. See Trained Specimens for Formal Planting, General Catalogue No. 50, for r903. Also specimens for single or group planting. Particulars and prices on application. For more complete list of varieties, descriptions, etc., see General Catalogue No. 50 , for 1903 .

ANDROMEDA Flori= bunda. One of the choicest Evergreen Shrubs. Dwarf, compact habit; small, dark green foliage; pure white Lily-of-theValley-like flowors; perfectly hardy. Fine bushy plants. \$I2 to $\$ 20$ per dozen; $\$ 50$ to \$IOO per Ioo.

ANDROMEDA Leuc $0=$ thœ or Catesbai. One of the finest American Shrubs ; bright red twigs; bell shape, Lily-of-the-Valley-like flowers. \$8 to \$I per Ioo.

ARALIA. Good plants of the Japonica, Pen= taphylla and Spinosa varieties. $\$ 2.50$ to $\$ 5$ per dozen. Low rates per ıoo.

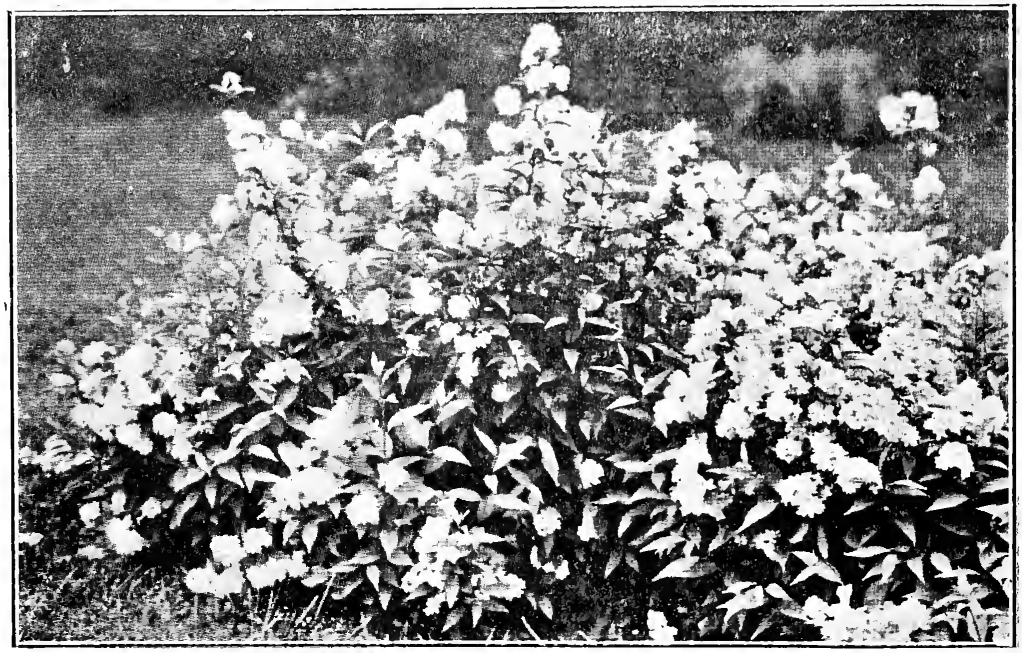

AZALEA Amœna. One of the most beautiful and valuable of low-growing shrubs. Very hardy, dwarf and compact, bushy habit and easily transplanted. Leaves thickly set on the branches, of fine, rich color, turning to a beautiful reddish brown or crimson in autumn and remaining on all winter. Flowers bright rosy red, and so profuse in May as to give the shrubs the appearance of a solid mass of bloom. $\$ 8$ to $\$ 20$ per dozen. Extra, $\$ 20$ per dozen.

AZALEA Ghent and Pontica. The best collections of these beautiful shrubs obtainable, made up of the best hardy varieties. Flowers in great profusion in spring, literally covering the branches. These plants remove with a ball and mass of fibrous roots, thus avoiding any risk in transplanting. Selected, well-budded plants, \$IO and \$I5 per dozen; extra, \$2O per dozen; $\$ 50, \$ 75$ and $\$ 100$ per roo. Extra specimens, 2 to 3 feet, 50 to 70 buds, very fine, $\$ 1.25$ per 100 . Special.

AZALEA Mollis. Perfectly hardy in most situations; also valuable for forcing; flowering early in profusion. Flowers very large, of various colors, in red, orange, primrose and yellow. The blooms appear on the ends of the branches, as with Rhododendrons. Very effec-
DEUTZIA LEMOINEI. (See page 7.)

tive in beds and masses, or in borders. Selected. well-budded plants, extra, \$Io and \$I5 per dozen; $\$ 35 . \$ 50$ to $\$$ Ioo per ioo.

AZALEA. Extra Exposition specimens. A limited stock of beautiful plants, 60 to 80 buds each; very fine for immediate effect. \$1.5O per Ioo.

AZALEA Mollis Standards. Fine specimens. grown in tree form, on stout stems. Fine flowering heads, full of buds that will bloom nicely first season. A desirable novelty. \$I 5 to \$25. per dozen.

ALTHAEA. Rose of Sharon. Fine plants of the best single and double sorts. Low rates per soo.

ALTH $\boldsymbol{A E A}$ Standard. New and beautiful shrubs, grown in tree form, with fine heads, on 3 to 4 feet stems. Good young specimens. Very fine. $\$ 1$ to $\$ 2$ each; \$1o to \$I8 per dozen.

ALMOND, Amygdalis. Double Red. Double White. \$3 and \$4 per dozen. Low rates per Ioo.

BERBERRY Thunbergii. Compact habit, bright foliage in autumn and red berries. Appropriately called "the finest shrub." Fine plants. $\$ 3$ to $\$ 5$ per dozen. Low rates per ioo.

BFRBERRY, Common American, European, Purple=leaved. Very fine plants. $\$ 2$ and $\$ 3$ per dozen; $\$ 5$ to $\$ 15$ per roo. 
BAY TREE. Laurus Nobilis. Fine specimens. See Sweet Bay Trees, page 9.

BACCHARIS Halimifolia. Dark green foliage. White Seed Pods. \$2 and \$3 per dozen. Low rates per Ioo.

BOX, Common Tree. Fine, bushy plants. \$I5 to $\$ 30$ per Ioo; smaller, \$Io per Ioo.

BOX, Dwarf. I have sent out thousands of yards of this "old-fashioned" edging plant, the stock giving excellent satisfaction. $\$ 30$ to $\$ 40$ per Ioo yards.

CALYCANTHUS. Fine plants. \$2 per dozen; $\$ 5$ to Io per Ioo.

CITRUS Trifoliata. Hardy Orange. Very fine; 2 to + feet. \$5 to \$I5 per Ioo.

CARYOPTERIS Mastacanthus. Beautiful blue Spiræa; blue fragrant flowers in autumn. \$3 and $\$+$ per dozen.

COTONEASTER Microphylla. Trailing habit; fine dark foliage; bright berries in the autumn. $\$ 2$ and \$3 per dozen. Low rates per I, ooo.

CORNUS, Red=branched and Variegated= leaved. \$IO to \$2O per Ioo.

CHIONANTHUS, or White Fringe. Large, rich foliage; fine. 30 to $50 \mathrm{cts}$. each; \$3 per dozen; \$2 to \$2O per Ioo.

CLETHRA Alnifolia. \$5 to \$Io per Ioo.

CRATAEGUS Pyracantha, Evergreen Thorn. One of the finest hedge plants. Special prices on application.

CYDONIA, or Japan Quince. Scarlet, White. Fine, bushy plants of different sizes for hedge or lawn planting. Fine stock; $\mathrm{I} 8 \mathrm{in}$. to $4 \mathrm{ft}$. $\$ 8$ to $\$ 30$ per Ioo.

DEUTZIA Gracilis. Low rates per Ioo.

DEUTZIA Crenata, and other leading kinds. 25 cts. each. Low rates per Ioo and I, ooo.

DEUTZIA Le Moinei. One of the best. Fine plants from \$I2 per Ioo up. See page 6.

DESMODIUM. Rose and purple flowers until frost; fine. 50 cts. $\$ 20$ and upwards per Ioo.

DIRCA Palustris. Low bushy habit. Yellow flowers. \$3 per dozen. Low rates per ıoo.

ELDER, Cut=leaved. Sambucus. $35 \mathrm{cts}$. each. Low rates per Ioo.

ELDER, Golden. Valuable for color contrast. $\$ 3$ to $\$ 5$ per dozen; $\$ 8$ to $\$ 20$ per Ioo.

EUONYMUS. Fine stock. Low rates per r,ooo.

EUONYMUS Radicans. See page II.

EUONYMUS Radicans Variegata. See page I I.

ELAEAGNUS Argentea. Erect growth, silvery foliage. 35 cts. each; \$I 2 to \$2O per Ioo.

ELAEAGNUS Longipes. $\$ 3$ and $\$+$ per dozen. Low rates per Ioo.

FILBERT, Purple=leaved. Large dark red leaves all summer. Fine plants. 50 cts. each; \$25 to $\$ 35$ per IOO.

FORSYTHIA Fortunei, \$3 per dozen. Low rates per Ioo.

FORSYTHIA Viridissima. Fine plants. $\$ 8$ to $\$ 20$ per Ioo. Low price per I, Ooo.

GENISTA Scoparia. The Scotch Broom. Very valuable for seashore planting. \$5 to $\$$ Io per Ioo. Special rates in quantity.
HAMAMEI.IS Virginica. Yellow flowers. Blooms late. \$3 per dozen. Low rates per ıoo.

HONEYSUCKLE. LONicERA. White, Red and Pink=flowering. Fine stock. $\$ 8$ to $\$ 20$ per Ioo. Low rates per I, ooo.

HYDRANGEA Paniculata Grandiflora. One of the most popular and valuable shrubs. Immense panicles of pure white heart-shaped flowers in August, turning to a delicate pink, and remaining until late in autumn. Fine plants. 25 to 50 cts. each; \$IO to \$30 per Ioo. Low rates per I, ooo.

HYDRANGEA Paniculata Grandiflora. Stand= ard. Nice specimens grown in tree form, about 5 feet, well furnished heads, rare, and very desirable for beds and borders. \$IO to \$I per doz.

HYPERICUM Aureum. Large yellow flowers from July to October. Fine. 5o cts. each; \$3 to $\$ 5$ per dozen.

HYPERICUM Calycinum. Low-spreading habit, completely covering the ground under trees or in shady situations. \$20 per Ioo.

HYPERICUM Kalmianum or St. John's Wort. $\$ 3$ to $\$ 5$ per dozen. Low rates in quantity.

ITEA Virginica. $\$ 2$ and $\$ 3$ per dozen. Low rates per Ioo.

LAUREL. Fine plants of the English Laurel; bushy, several times transplanted. \$20 to \$40 per Ioo.

LAUREL, Kalmia Angustifolia. Red flowers. Low rates per Ioo and I,Ooo.

LAUREL, Kalmia Glauca. Very effective for mass planting. \$2 and \$3 per dozen; \$Io to $\$ 20$ per Ioo.

LAUREL, Kalmia Latifolia. The beautiful Mountain Laurel. Nursery-grown plants are as easily transplanted as any other hardy shrub. Can be transplanted in the autumn with perfect safety, or wili enter orders for spring shipment as desired. Soil and treatment required similar to the Rhododendrons. Fine specimen plants for immediate effect from 2 or 3 feet high up to + to 6 feet in height and of nearly same diameter, well-furnished and well-budded, with large balls, are furnished in carload lots at exceptional rates. See General Catalogue No. 50 for I903, and write for prices and particulars. Fine, well-budded nursery-grown plants, several times transplanted, with ball, from 9 to I2 inches up, from $\$ 6$ to $\$ 20$ per dozen, and at special prices per Ioo and I, ooo. A limited number of large specimens at special prices. Selected native plants, well-budded, I to 2 feet, 2 to 3 feet, and larger, \$Io per Ioo and upwards. Special price per I, ooo on application.

KERRIA Japonica and Variegata. Beautiful golden globular-shaped flowers. Fine plants $\$ 3$ and $\$+$ per dozen. Low rates per Ioo.

LILAC, Common Purple, Common White. Fine plants; different sizes. \$IO to $\$ 20$ per Ioo. Smaller plants, low rates per I, ooo. Best named, new and rare varieties. Fine plants. $\$ 5$ to \$Io per dozen. Special prices per Ioo and for choice collections.

LILAC, Japonica Alba. Flowers in immense pure white trusses. Fine stock of this grand variety. $\$ 5$ to $\$$ Io per dozen. 
MAHONIA Aquifolium. Large, shining, purplish green prickly leaves. Special prices per IoO and I,ooo.

MYRICA Cerifera. The wellknown Bayberry or Wax Myrtle. Spreading, bushy habit; rich foliage; white berries in autumn. \$3 per dozen. Low rates in quantity.

PHILADELPHUS. SYRINGA. The common sweet SYRINGA; 25 to 50 cts. each; $\$ S$ to $\$ 20$ per Ioo. Very low rates per I, ooo.

PHILADELPHUS, Golden. Compact habit; foliage bright yellow; fragrant white flowers. Fine. 50 cts. each; $\$ 3$ to $\$ 5$ per dozen. Special low rates per IOO.

PHILA DELPHUS, Speciosa, Grandiflora and other best sorts Fine plants, $\$ 3$ per dozen; $\$ 8$ to $\$ 20$ per Ioo.

PURPLE Fringe. Rhus Cotinus. "Smoke Tree." 35 cts. \$io to

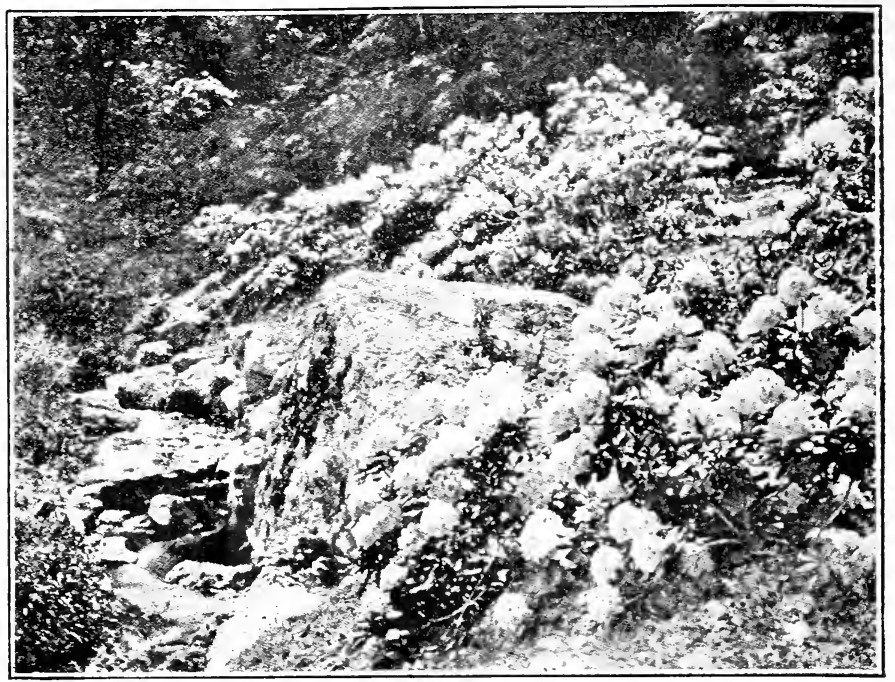
$\$ 20$ per Ioo.

PRUNUS Pissardii. Leaves constant crimson or maroon red the entire season. Fine plants, $\$ 3$ to $\$ 5$ per dozen. \$1o to $\$ 25$ per Ioo.

PRIVET, California. One of the best and most popular hedge plants. Fine plants of all sizes from $\$ 15$ per I, ooo up. Special prices in quantity.

PRIVET, Common European. A valuable hedge plant, and for groups, screens or borders. Very compact habit; different sizes. Low rates per IOO and I,OOO.

PRIVET, Standard. Fine plants grown in tree form and used like LaUrus Nobilis (Bay Trees), for formal gardening or decoration. Good young specimens on 3 to 5 feet stems, $S_{5}$ to \$io per dozen. Also extra specimens. Prices and particulars on application. See General Catalogue No. 5 o for 1903.

PEONIES, Upright or Tree. Enormous showy flowers. Best hardy varieties, SI to $\$ 2$.

RHODOTYPUS kerrioides. Large, dark, plicate foliage and single pure white flowers.

RHAMNUS or Buckthorn. Good plants for ornamental planting or for hedge. $\$ 2$ to $\$ 4$ per dozen; Io and \$I5 per Ioo.

RHODODENDRONS. Best hardy named varie= ties. For many years these fine hardy Rhododendrons have been one of my leading specialties. All my plants are well grown, several times transplanted, bushy, well budded, well furnished and are only of the "iron clad" tested varieties that with ordinary treatment will succeed anywhere in the central and northern States.

The Case Collections of 25, 50 and roo plants, each case as furnished heretofore, can be relied upon to give excellent satisfaction. The assortment of varieties and colors is made with the view of obtaining the best effects for the number

HARDY NAMED RHODODENDRONS.

of plants in each case. These cases of 25,50 and Ioo plants are furnished uniformly at the wholesale price, or hundred price, as quoted.

Pricrs: Bushy, well budded plants, several times transplanted with ball, 15 to 20 in. \$1 2 per dozen, \$75 per Ioo; IS to 20 in., \$I5 per dozen, SIOo per IOo; selected plants, I8 to 24 in., SI8 per drzen, SI25 per Ioo; selected extra size plants, 2 to 3 feet, $\$$ IS to $\$ 25$ per dozen.

For List of varieties, etc., see General Catalogue No. 50 for I903.

RHODODENDRONS. Best Hardy Seedlings. Fine colors; good, bushy, transplanted plants with buds, from Sto to $\$$ Ioo per Ioo. Special prices per I,Ooo for best named kinds of Seedlings, on application.

RHODODENDRON maximum. ROSE BAY or GREAT LAUREL. The native species found so abundantly in the Eastern and Central Southern States. Very large, bold and handsome foliage; white and rose-colored flowers in midsummer; blooms later than other Rhododendrons. Selected plants, I to 2 and 2 to 3 feet, $\$ 25$ to $\$ 75$ per Ioo. Low rates in quantity.

Also fine selected specimens from 2 to 3 feet up to $S$ :o ro feet in height, and of corresponding diameter, are furnished in carload lots at special prices. These plants are all grown in the open: bushy, well furnished to the ground, and are dug and packed with large solid balls, being quite different from the poorly furnished plants from the woods sent out by many firms. See Special Circular, also General Catalogue No. 50 for 1903 , for further information and prices.

RHODODENDRON Ponticum. Half-hardy. Suitable for planting in California or the Southern States. Bushy and well-budded plants, I to 3 feet, $\$ 25$ to $\$ 75$ per ioo. For further description of all varieties of Rhododendrons see General Catalogue No. 50 for I903.

In reply to your queries about Rhododendrons I was much pleased with them, and they are doing nicely. Lenox Mass 
SEA BUCKTHORN, Hippophæ. Very valuable for seashore planting.

SPIRAEA, Bumaldi. Similar to Waterer. Rosecolored flowers in mid-summer. Very fine. \$3 and \$+ per dozen; \$10 to \$20 per roo.

SPIRAEA, Crenata, Douglassii, Eximia, For= tuni, Lance=leaved, Robusta and other leading kinds. $\$ 2$ and $\$ 3$ per dozen; $\$ 6$ to $\$ 20$ per IOO.

SPIR $A A$, Golden=!eaved. A very fine effective shrub for groups. Special low rates per roo and $\mathrm{I}, \mathrm{OoO}$.

SPIRAEA, Prunifolia, or Bridal Wreath. 35 cts. each. Low rates per Ioo and $\mathrm{I}, 000$.

SPIRAEA, Thunbergii. $25 \mathrm{cts}$. each; $\$ \$$ to $\$ 20$ per IOo; very low rates per I, Ooo.

SPIRAEA, Tomentosa alba. New white. Similar growth and foliage to the pink tomentosa. $\$ 3$ per dozen.

SPIRAEA, Van Houtteii. One of the finest hardy flowering shrubs. 35 cts.; $\$ 8$ to $\$ 20$ per Ioo.

SPIRAEA, Waterer. Bright crimson flowers. Hardy. New and fine. $\$_{3}$ to $\$_{5}$ per dozen; $\$$ Io to $\$ 20$ per IoO.

SNOWBERRY. SYMPHORICARPUS. Racemosa and Vulgaris. \$3 per dozen. Low rates per IOO and I,OOO.

SWEET BAY TREE. Laurus Nobilis. Fine Standards, with straight stems and solid heads. Is inches to $S$ feet or more in diameter. Well- shaped Pyramids, 3 to ro feet and upwards in height. Special quotations, with particulars, sizes, etc., on application. See General Catalogue No. 50 for I903.

TAMARIX. Strong plants, 25 cts. each; $\$ 6$ to \$2O per Ioo.

VIBURNUM, Lantana-leaved, Common Snow = ball, Rugosum, etc. Fine plants. 25 to $50 \mathrm{cts}$. each; $\$ \$$ to $\$ 20$ per Ioo. Very low rates per I,OOO.

VIBURNUM, Plicatum. Beautiful Japan Snowball. 25 to $75 \mathrm{cts}$. each. Low rates per Ioo.

VIBURNUM, Standard. Good specimens grown in tree form of both the Common Snowball (V. Opulus Sterilis) and the beautiful Japan Snowball (V. Plicatuir). Stout stems, 3 to 4 feet. Well branched heads for early flowering in desirable novelties. Fine for beds and borders used as a background to low-growing shrubs and herbaceous borders. \$10 and \$15 per dozen.

WEIGELA, A mabilis, White=flowering, Rubra, Rosea, Variegated=leaved. $\$ 3$ and $\$_{+}$per dozen; \$S to \$2O per IOO

XANTHOCERAS. A magnificent hardy flowering shrub. 75 cts. each; $\$$ to $\$ 6$ per dozen.

XANTHORHIZA. Low spreading habit; fine for massing. \$2 and \$3 per dozen.

YUCCA, Filamentosa. Adan's NeEdle. Fine plants. $\$ 3$ to $\$+$ per dozen; $\$$ io to $\$ 20$ per Ioo.

\section{SPECIAL COLLECTIONS OF HARDY SHRUBS.}

The following collections comprise the best hardy varieties, both in flower and foliage, and give a succession of bloom from the Cedonias, Forsythias and Lilacs, in April, to the Hydrangeas, Hibiscus, etc.. in late autumn. All are perfectly hardy, NiCEly braNched aNd ROOTED, aNd of the Best SIZES FOR IMIMEDIATE EFFECT.

No. 1. 50 Choice Shrubs, in 20 to 25 leading varieties... $\$ 10.00$; extra, $\$ 12.50$

No. 2. 100 " " 25 to 30 " 20 " 2.20 .00 ; " 25.00

No. 3. 100 " " " general assortment........12.00; " 18.00

These collections have given excellent satisfaction to the many country estates, where I have supplied them for a number of years past.

I have also this season very fine ExTRA SIZE SHRUBs of the leading hardy varieties, bushy, + to 7 feet, suitable for immediate effect for screens, etc. Prices and particulars on application.

\section{SMALL TRANSPLANTING SHRUBS.}

Leading varieties: Berberries, Cornus, Cyuovia (Japanese Quince), Deutzias, Forsythias, Elders, Hydraxgeas, Lilacs, Mahonia, Philadelphus (Syringa), Privet, Spir æas, Viburvum (Snowball), Weigelas, etc. I furnish in GOOD ASSORTMENT, MY SELECTION, at $\$ \mathbf{5 0}$ to $\$ \mathbf{1 0 0}$ per $\mathbf{1 0 0}$, accord= ing to size.

NATIVE SHRUBS. Can furnish large selection of best varieties. Fine for rough plant= ing. Write for prices and particulars. 


\section{Best Hedgé Plants.}

The Following COMprise the best of the hedge plants, both Deciduous and Evergreen. All are fine, well rooted and properly transplanted.

For further information and additional varieties see General Catalogue No. 50 for 1903.

$\begin{array}{lll}\begin{array}{l}\text { Buckthorn (Rhamnus), } \\ \text { Calitornia Privet, }\end{array} & \begin{array}{l}\text { Cydonia (Japan Quince), } \\ \text { Honey Locust, }\end{array} & \begin{array}{l}\text { Arbor Vitæ, American and Siberian` } \\ \text { Box (Buxus), } \\ \text { Common Privet, }\end{array} \\ \begin{array}{c}\text { Lilac, } \\ \text { Cratæous Pyracantha (Evergreen, } \\ \text { Thorn), }\end{array} & \begin{array}{l}\text { Osage Orange, } \\ \text { Rosa Rugosa, }\end{array} & \text { Norway Spruce. }\end{array}$

Fine Plants, Different Sizes. Special prices per 100 and 1,000 on application.

\section{Climbing' Vines and Trailing' Shrubs.}

OF THE HARDY vines the following list embrace those most desirable. Many other varieties can be furnished. The Ampelopsis, Honeysuckle and Cematis are especially fine.

For further information and other varieties see General Catalogue No. 50 for 1903.

ACTINIDIA polygama. From Japan. Fine and rare. 75 cts each; $\$ 5$ and $\$ 7.50$ per dozen.

AMPELOPSIS Englemanni. Glossy foliage, crimson in autumn: very fine. $50 \mathrm{cts}$ each; $\$ 5$ per dozen.

AMPELOPSIS, Quinquefolia, American Ivy or VIRGINIA CREeper. $35 \mathrm{cts}$. each; \$Io to \$2O per IOO.

AMPELOPSIS Veitchii. Fine plants. \$3 to \$6 per dozen, Low rates per Ioo and I,ooo.

ARISTOLOChIA Sipho, or Dutchman's Pipe. Leaves 8 to 12 inches in diameter. Curious pipe-shaped yellowish-brown flowers; rapid growth. \$5 per dozen. Low rates per ıoo.

CELASTRUS Scandens. Strong vines, \$3 per dozen. Low rates per Ioo.

CLEMATIS, Baron Veillard. New and distinct. Flowers satiny pink or rose color; remain in perfection for weeks. Hardy and a profuse bloomer. \$I and \$I.50 each; \$IO per dozen.

CLEMATIS, Coccinea, Flammula, Virginiana. 25 to 50 cts. each. Low rates per Ioo and I, ooo.

CLEMATIS, Henryi, Jackmanni, and other varieties. Strong plants. 50 cts to $\$ \mathrm{I}$ each. Low rates per Ioo.

CLEMATIS, Madame Edouard Andre. A grand new variety of the Jackmanni type. Vine vigorous and hardy. Flowers large, vivid crimson, and produced in great abundance. The first fine crimson variety of the large free flowering Clematis yet introduced. Should be in every collection. Fine plants $\$ \mathrm{I}$ and $\$ \mathrm{I} .50$ each; \$Io and \$I5 per dozen.
CLEMATIS, Paniculata. Rapid growth; large dark, shining green leaves; delicate, fragrant white star-shaped flowers in large panicles, followed by seed-pods of bronzy tint; perfectly hardy. \$2 to \$5 per dozen. Low rates per Ioo and $\mathrm{I}$,ooo.

HONEYSUCKLE. LONICERA. Common Wood= bine, Golden=leaved, Scarlet Trumpet. Fine plants. \$3 per dozen. Low rates per I,ooo.

HONEYSUCKLE, Hall's Japan Evergreen. One of the finest of all climbing shrubs. Very hardy. Profuse bloomer all summer. Very fine stock. \$2 and \$3 per dozen; \$1o to \$2O per IOO; \$50 per I,ooo.

IVY. Hedera. English, Giant, Irish Varie= gated. \$3 and \$4 per dozen. Low rates per I, ooo.

JASMINE, Yellow=flowering, White. Fine plants, \$3.50 per dozen.

LYCIUM Chinensis, or Matrimony Vine. Strong vines, \$3 and \$4 per dozen; \$8 to \$I5 per Ioo.

SILK VINE. PERIPloca. Very hardy, rapidgrowing vine, suitable for covering trees, etc. $\$ 3$ per dozen; \$1o per Ioo for strong vines.

TRUMPET Flower. Tecoma or Bignonia. 25 and 35 cts. each; $\$ 2$ and $\$ 3$ per dozen. Low rates per I,ooo.

WISTARIA, Chinese, Magnifica, White=flow= ering. 50 cts. each; $\$ 5$ per dozen. Low rates per IOo.

WISTARIA, Purple. Fine plants, $\$ 3$ to $\$ 6$ per dozen. Special prices in quantity. 


\section{TRAILING VINES FOR COVERING GROUND IN SHADED PLACES.}

The Following are the best of the Hardy Trailing Vines with creeping habit, for covering bare spots under trees and shaded places. All are easily and successfully grown. $\$ 2$ and $\$ 3$ per dozen.

For More Complete List see General Catalogue No. 50 for 1903. Special low prices per 100 and 1,000 on application.

EPIG $A$ A Repens. Ground Laurel, Trailing Arbutis, or Mayflower of New England. Evergreen heart-shaped leaves; rose-colored flowers early in spring.

EUONYMUS Radicans. Hardy evergreen vine of clinging habit like the Ivy. Much slower growth. Low prices in quantity.

EUONYMUS Radicans Variegata. Trailing vine, with clinging tendrils. Variegated small leaves. Fine.

HERNIARIA Glabra. Dense green foliage, changing to a bronzy crimson in autumn; forms a solid covering.
MITCHELLA Repens. Shining, round leaves, often variegated with white. \$5 per Ioo. Special prices per I,ooo.

LYSIMACHIA Nummularia. M O N Y W O T Small, round leaves; close, spreading habit.

NEPETA Glechoma. Ground Iry. Of compact growth, and has a solid mat of pretty green foliage. $\$ 3$ to $\$ 5$ per IOO; \$IO to \$2O per I,OOO.

VERONICA Crecaoides. Grows but a few inches high; flowers bright blue, in spikes, in early summer.

Vinca Minor. Comion Periwinkle or Blue Myrthe. Evergreen verdure and blue flowers. $\$ 2.50$ to $\$ 5$ per IOO; $\$ 20$ to $\$ 30$ per I,OOO.

\section{Hardy Herbaceous Plants.}

\section{Nursery Grown.}

The General Appreciation and increased demand of late for "old-fashioned gardens," bring largely into use the more free flowering and effective herbaceous plants. In formal gardening they are indispensable, and most desirable in every border or flower garden, not only for the showy bloom all through the season, but for cut flowers as well.

The Following are only a few of the many herbaceous perennials I am furnishing, of excellent quality, at lowest prices. Estimates for particular kinds and quantities, or for planting a garden complete, given on request; also suggestions for arrangements for effective planting, without charge.

For More Complete List, see General Catalogue No. 50 for 1903.

Low prices per 100 and 1,000 on the following:

ACHILlEA. Yarrow. Best varieties; fine. \$2 and $\$ 3$ per dozen. Low rates per roo.

ANEMONE, Japonica, Alba and Rosea. Bloom from August to November. Beautiful white or rose flowers in profusion. Very fine. \$3 per dozen. Special price per Ioo.

ARUNDO. Donax and Variegata. \$3 to \$5 per dozen. Low rates per Ioo and I,ooo.

ASTERS. Fine plants of the large, splendid varieties. \$2 and \$3 per dozen.

AQUilegia. Columbine. Beautiful varieties; fine plants. \$3 and \$4 per dozen.

ASTILBE Japonica. JAPAN SPIRÆA. Fine. \$2 and $\$ 3$ per dozen.

BEGONIAS, Tuberous=Rooted. Best single and double. \$2 and \$3 per dozen.

CAmpanula. Blue Bells or Bell Flower. Best varieties. $\$ 2$ and $\$ 3$ per dozen.

CONVALLARIA. Lily-OF-The-VAlLey. Strong, hardy clumps. \$4 per dozen; $\$ 15$ to $\$ 25$ per roo. For Forcing Pips, see page I3.

DAHLIAS. Special collections of the finest single and double varieties; very fine. $\$ 3$ and $\$ 4$ per dozen. Low rates per Ioo.

DELPHINIUM. Larkspur. Leading kinds. \$2 and $\$ 3$ per dozen.
Dicentra. Bleeding Heart. Low rates per JoO.

Digit ALIS. Fox Glove. \$3 per dozen.

DIANTHUS. HaRdy Pink. \$2 and \$3 per dozen.

ERIANTHUS Ravennæ. GRASS. Hardy and fine. \$3 per dozen; \$1o to \$20 per Ioo.

EULALIA Japonica var. Zebrina. Fine. \$ ro to $\$ 20$ per roo.

FUnKIA. Plantain Lily. \$2 and \$3 perdozen.

GAILlaRdia. Blanket Flower. Very showy. $\$ 2.50$ per dozen.

HElianthuS. Sunflower. Showy kinds.

HIBISCUS Moscheutos, and other best sorts.

HOLLYHOCKS. Choice selection of the FINEST DOUbLE VARIETIEs. Strong flowering roots, \$3 to $\$ 5$ per dozen. Low rates per Ioo.

HEMEROCALlis. Day Lit.y. \$2.50 per dozen.

IRIS Germanica. Strong flowering roots, \$2 per dozen; extra, \$2.50 per dozen; \$8 to \$I5 per Ioo.

IRIS Kæmpferi. Beautiful Japan IRIS. Perfectly hardy and easily grown. Flowers extra large, 6 to 8 inches in diameter, in various tints of purple, lavender, blue, shaded with yellow and straw color, etc. In beds or borders these plants give a mass of bloom for several weeks in summer. Special collection of the finest 
Premium varienies. Strong flowering Clumps. $\$ 5$ per dozen; $\$ 35$ per Ioo. This is the finest stock obtainable here or in Japan. Good mixtures, strong clumps, \$Io to \$2O per Ioo.

LIATRIS. Blazing Star. \$2.50 per dozen.

LILIUM. L!lies. See page I 2.

LOBElla. Cardinal Flower. Fine.

MALVA. Mallow. Fine. \$2.50 per dozen.

PAPAVER. Poppy. Very showy. \$3 per dozen.

PAEONIES. Fine flowering roots of the best hardy kinds. White, Red, Scarlet, Pink, etc., including the large flowering Chinese varieties. Special low price per I, ooo. $\$ 3$ to $\$ 5$ per dozen; $\$$ I 2 to $\$ 25$ per IOo.

PAEONY Trnuifolium. Large carmine, crimson; single flower; fine feathery foliage; very fine. $\$ 5$ per dozen.

PHLOX. Beautiful free-blooming upright border plants. Many varieties. Fine. \$2 and \$3 per dozen. Low prices per Ioo.

NATIVE HERBACEOUS PLANTS. Very effective for mass planting. Large assortment of varieties. Write for prices and particulars.
PHLOX, Subulata, or Moss Pink. Form a beautiful carpet of verdure; white flowers.

PRIMULA. Primrose. \$2 and \$3 per dozen.

PYRETHRUM. FEVERFE. Fine. \$2 and \$3 per dozen.

RANUNCULUS. Buttercup. \$2.50 per dozen.

RUDBECKIA Laciniata fl. pl. The finest hardy Rudbeckia; rich foliage and mass of beautiful golden-yellow flowers. Fine stock. \$5 to \$IO per Ioo. Low rates per I, ooo.

SOLIDAGO. Golden Rod. Very showy. \$2 per dozen.

SPIRAEA. Meadow Sweet. Very beautiful.

SEDUM. STONE CRop. \$2 per dozen.

Tritoma. Poker Plant. Immense spikes of crimson flowers. \$2 and \$3 per dozen.

VINCA. Periwinkle. See page i i.

VIOLA. Sweet Violet. Best varieties. \$2 and $\$ 3$ per dozen.

\section{Choice Hardy Bulbs.}

LILIES. Hardy lilies bloom in MIDSUMmer when few flowers are out. They are very effective planted in beds by themselves or IN BEDS of RHoDodendRons, or in beds or borders of other hardy shrubs.

Collections of the Best Varieties of Hardy Lilies for Outside Planting, Selected Bulbs, as Follows:

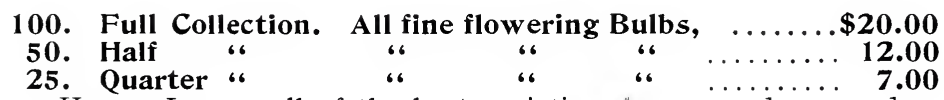

Other Choice Hardy Lilies, all of the best varieties, \$2.50 per dozen and upwards. Special low prices per ioo. Send for quotations.

For a complete list of Hardy Lilies, with description, etc., see page 61, Catalogue No. 50 for 1903.

\section{BULBS FOR LAWN AND OUTSIDE PLANTING.}

Special low prices for the following per i, OOo. For Forcing Bulbs, see page i3.

CROCUS, Best Named, \$I per IOO, extra, \$I. 50 per Ioo. Mixed, 75 cts. per Ioo.

HYaCINTHS, Best Named Single and Double. The finest varieties. \$I.50 to \$2.50 per dozen. Prices per roo on application.

HYACINTHS, Best Mixed for Bedding or Forc= ing. Selected in colors; fine. $\$ 5$ to $\$ \$$ per Ioo.

HY ACINTHS, Early Roman White. Selected and extra bulbs. \$I and \$I.5O per dozen.

HYA CINTHS, Roman, Blush Rose, Dark Rose, Blue, White Italian. \$I per dozen; \$5 per roo.

TULIPS, Choicest Named, Single and Double. Selected. \$5 per Ioo: fine bulbs at very low rates per I,ooo. Parrot Tulips. Fine named. $\$ 3$ per roo.
TULIPS, Fine Mixed in Colors, for Bedding or for Forcing. \$2 per Ioo; extra, \$3 per Ioo. Special low rates per I, ooo on application.

NARCISSUS, Von Sion, Double White, Double Yellow, Poeticus, etc. Selected bulbs for outside planting. $\$ 2.50$ and $\$ 3.50$ per Ioo.

NARCISSUS, Yellow Trumpet, Paper White, and other best kinds for forcing. $\$ 2.50$ to $\$ 5$ per Ioo.

ANEMONES. Fine. \$5 per Ioo, Crown Im= perials. Selected. $\$ 3$ to $\$ 5$ per dozen. Snow $=$ drops. \$2 per Ioo; extra, \$3 per Ioo. Jonquils. $\$ 3$ per roo. Oxalis, \$3 per roo. Scillas, \$3 and $\$+$ per Ioo. 


\section{Forcing Plants and Bulbs.}

AZALEA Indica. Of these beautiful flowerplants I make direct importations of TRAINED SPECIMENS of different sizes and the choicest named varieties of brilliant colors. They can be sent with safety at any time during the autumn and early winter for blooming the coming season. My plants are carefully selected with COMPACT TRAINED HEADS, so that when they flower they are a SOLID MASS OF BLOON on an almost uniform even surface, and produce a rery beautiful effect. Specimen plants, I to 2 feet diameter of head, \$1o to $\$ 25$ per dozen. Smaller plants, \$35, \$50 to \$roo per ioo. Particulars as to sizes, prices, etc., on application.

AZALEA Mollis. Bushy, compact plants, full of buds. Specially grown and of the best plants for forcing. $\$ 5$ and $\$ 7.50$ per dozen. Low prices per IoO.

HYACINTHS, Narcissus, Tulips, Etc. See “Choice Hardy Bulbs," page I 2.

LILY=OF=THE=VALLEY. Best Berlin pips, extra 3 years. \$2 per Ioo. Special prices per I,, 00 .
LILACS. Fine plants; full of buds; specially grown for forcing. Leading varieties. $\$ 7.50$ and Sio per dozen. Price per roo on application.

BERMUDA Easter Lily, LILIUM HARRISII. Selected and extra bulbs, $s$ to 9 and 9 to 12 inches in circumference, SI 2 o to $\$ 25$ per roo. Smaller, good bulbs, $\$ 5$ to $\$$ Io per Ioo.

CANDIDUM Lily. Selected and extra size bulbs. SI and SI.5O per dozen; SIo and SI5 per Ioo.

LONGIFLORUM Lily. 7 to 9 and 9 to $\mathrm{I} 2$ inch extra bulbs, $\$ 2$ and $\$ 3$ perdozen; $\$ I_{5}$ to $\$ 25$ per roo. Smaller, good bulbs, $\$ 7$ and $\$$ Io per Ioo.

FREESIA Refracta alba. $\$_{2}$ and $\$_{3}$ per roo; $\$ 15$ to $\$ 25$ per 1,000 , according to size.

SPIR AEA Japonica. Large clumps. \$1.50 per dozen: S Io per ıoo. Low rates per I, ooo.

RHODODENDRONS. Selected, bushy, wellbudded plants of best kinds for forcing. S9 to \$I5 per dozen; extra, \$IS to \$25 perdozen; $\$ 75$ to $\mathrm{S}$ I5o per roo. Particulars on application.

ROSES fur Forcing. See "Choice Roses" and List of Varieties below; also Catalogue No. 5o for 1903 .

\section{Choice Roses.}

FINe Roses are one of my leading specialties; BUDDED or ow ROOT PLANTS, per IOO and I, oOO at low prices. Also EXTRA FINE STANDARD ROSFs.

The Hybrid Perpetuals are hardy, and, as a rule, the most satisfactory for outside planting.

All Roses require rich soil and liberal treatment. Close pruning is important. Good mulching in autumn is desirable.

I Offer This Autumn remarkably fine Hardy Roses, Hybrid Perpetuals, strong Oxe and Two-Year PlaNts, BUDded or ox ROOTS FOR PLANTING OUTSIDE. Also, fine pot-grown plants of the best kinds-Hyrid Perpetual, Teas, Etc., for Forcing.

The Following are a few of the leading varieties.

For more complete lists, descriptions, etc., see Catalogue No. 50 for 1903.

\section{BEST HYBRID PERPETUAL ROSES.}

Abel Carriere, Alfred Colomb, American Beau= ty, Anna de Diesbach, Baroness Rothschild, Baron de Bonstettin, Baronne Prevost, Clio (rosy pink), Coquette des Alpes, Charles Le= febvre, Countess of Oxford, Dinsmore (fine crimson), Duke of Edinburgh, Earl of Dufferin (magnificent dark velvety crimson), Etienne Levet, Eugene Verdier, Fr ıncois Levet, Fran= cois Michelon, Fisher Holmes, Gen. Jacque= minot, Gen. Washington, Helen Keller (bright satin rose), Jubilee (pure red), John Hopper, Jules Margottin, La France, La Reine, Louis Van Houtte, Marchioness of Dufferin, Mad. Gabriel Luizet, Mad. Plantier, Mabel
Morrison, Marguerite de St. Armande, Marchioness of Lorne (new; large, beautiful carmine; fine), Magna Charta, Mar= garet Dickinson (superb white), Marie Bauman, Mrs. Crawford (deep rosy pink), Marshall P. Wilder, Merveille de Lion, Mar= chioness of Londonderry (extra large, fine white), Mrs. J. Laing, Madame Plantier, Paul Neyron, Persian Yellow, Pierre Notting, Prince Camille de Rohan, Sir Roland Hill (fine, dark purple). Ulrich Brunner, (see page I4), Victor Verdier, Xavier Alibo, and others. Strong, Fine Two-Year Plants, s3 to $\$ 6$ per dozen; SI 5 to $\$ 35$ per Ioo. Smaller plants, Sio and $\mathrm{SI}_{5}$ per Ioo. Speciai prices per $\mathrm{I}, 000$.

\section{ROSES FOR FORCING.}

Leading kinds, American Beauty, Belle Sie= brecht, Bennett, Bridesmaid, Bride, Bon Silene, Mermet, Duchess of Albany, Golden Gate, Gontier, Hermosa, Kaiserin Augusta Victoria, La France, La Marque, Mrs. Pier= pont Morgan, Mad. Cusin, Malmaison, Mad. Watteville, Maman Cochet, Mme. Hoste, Marechal Niel, Meteor, President Carnot, Niphetos, Perles, Souv. d'un Ami, Clothilde Soupert, Testout, Sunset, etc. From $2 \frac{1}{2}, 3$ 
and + inch pots, and larger. \$ Io to \$20 per Ioo. Also the best Hybrid Perpetuals, Jacqueminot, Mrs. Laing, Paul Neyron, Magna Charta, etc. Special prices on large orders.

\section{CLIMBING ROSES.}

CRIMSON RAMBLER (a grand variety), Yellow Rambler, Empress of China, Baltimore Belle, Gem of the Prairies, Jules Margottin, Mrs. Hovey, Queen of the Prairies, etc. Strong, fine plants. \$3 to \$5 per dozen. Special prices per Ioo.

\section{OTHER DESIRABLE ROSES.}

AGRIPPINA, Dawson, Harrison's Yellow, Cab= bage Rose, and other special varieties. $\$ 3$ and St per dozen: SI 5 to $\$ 25$ per Ioo.

MADAME GEORGES BRUANT. Flowers pure white; dark, rugosa-like foliage; very hardy.

MOSS ROSES, Crested, Gracillis, Blanche Moreau, Common Moss, Madame Edward Ory, Salet, etc. Strong plants. \$4 to $\$ 6$ per dozen. Special prices per Ioo.

ROSA MULTIFLORA JAPONICA. Fine. \$2.50 per dozen: \$Io per Ioo.

ROSA RUGOSA. One of the most desirable. Especially fine for mass or hedge planting, Fine plants of both Alba and Rubra $\$_{3}$ to $\$_{5}$ per dozen. Sio to $\$ 20$ per Ioo. Low rates in quantity.

ROSA SETIGERA. Low rates per Ioo.

STANDARD, or Tree Roses. Very fine plants. Best hardy varieties, $75 \mathrm{cts}$. and $\$ \mathrm{I}$ each; $\$ 6$ to

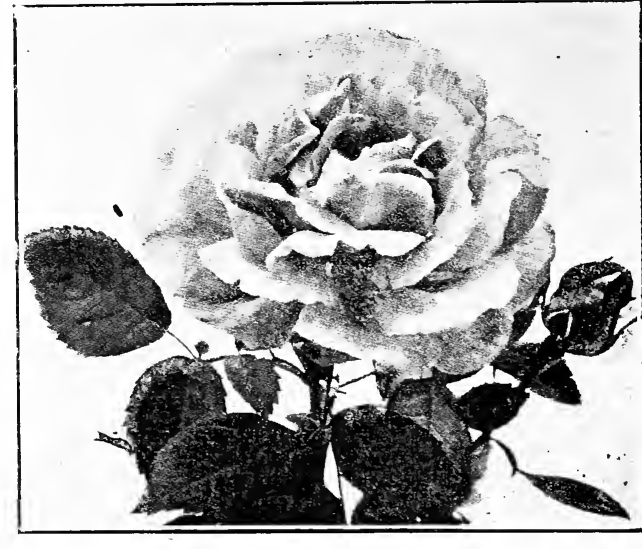

ULRICH BRUNNER.

(See page 13.)

\$io per dozen; extra home-grown plants, \$I.50 each; \$I5 per dozen. Extra Specimens, Exposition Standard Roses, Plants with Extra Stenis About i-INCh Caliper.

SWEET BRIER. Rosa Rubiginosa. The best of Penzance hybrids: also the old English Sw eet Brier. \$3 to \$5 per dozen; $\$ 25$ to $\$ 75$ per I, OOO.

ROSA WICHURAIANA. Very rapid growth. Very fine for covering ground, steep banks, etc.. where grass fails, $\$ 3$ to $\$ 5$ per dozen; $\$ 10$ to $\$ 20$ per Ioo. Special prices per I,ooo.

\section{SPECIAL COLLECTIONS OF THE BEST HARDY ROSES.}

These collections are made up of the choicest and most desirable kinds for outside beds or borders. The plants are dormant, mostly on own roots, of large size, and selected for immediate flowering, with ordinary treatment, the first season.

Collection of 50 Best Hardy Roses, \$12.00; extra, \$15.00.

Collection of 100 Best Hardy Roses, $\$ 20.00$; extra, $\$ 25.00$.

Smaller Plants, \$10 and \$15 per 100 ; best varieties, as above, and in Catalogue No. 50 for 1903.

\section{Choice Fruits.}

Autumn is favorable to the planting of nearly all hardy fruits. The Apples, Pears, Cherries, Plums, Quinces and Small Fruits offered are the best quality and strictly reliable. Extra or bearing sizes of many varieties can be supplied of extra fine trees this season, AT LOWEST PRICES.

\section{TRAINED FRUIT TREES FOR FRUIT HOUSES OR GARDENS.}

For a number of years I have made this branch of the business a specialty, and have supplied the trees and Exotic grapevines for many of the best Fruit Houses in the country. With direct importations, I have exceptional facilities for furnishing Espaliers, Cordons, Fan Trained, Hori= zontal Trained trees of different sizes and best varieties for forcing or outside planting in any quantities desired and at reasonable prices. Prices and particulars on application.

For List of Varieties of the leading Fruits, descriptions, etc., see Catalogue No. 50 for I903. Where large orders per IOo or I, OOO are required. SPECIAL LOW PRICES will be given.

APPLES, Standard or Dwarf. Selected trees of all leading sorts. Very fine this autumn. Sum= mer, Autumn and Winter. $\$ 3$ to $\$ 5$ per dozen ; extra, fruiting sizes, $\$ 9$ to $\$ 18$ per dozen. Low prices per I, Ooo.
NECTARINES. Leading kinds for forcing or growing outside at reasonable prices.

QUINCES. Best kinds for market or garden, \$4 to $\$ 6$ per dozen. Low rates per Ioo.

PEACHES. For Fruit Houses, Peaches should 
always be grown on plum stocks. Fine trees of the best kinds, for this purpose, also fine trained specimens, my own importations, SIo to $\$ 30$ per dozen. For outside planting, selected trees, leading sorts, $\$ 3$ to $\$_{5}$ per dozen. Very low rates per 100 and $\mathrm{I}$, ooo.

PEARS. Splendid trees of all sizes and best ra-

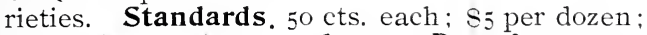
extra, Sio to Sis per dozen. Dwarfs, to cts. each; \$+ per dozen; extra fruiting sizes, \$I to $\$ 25$ per dozen. Low rates for leading kinds per IOO or I,OOO.

PLUMS. Very fine stock of all leading kinds, 50 cts. each: $\$ 5$ per dozen: extra, $\$ 6$ to $\$$ io per dozen. Special prices in quantity.

CHERRIES. Fine trees of the best standard kinds; large, sweet and sour varieties. $S_{5}$ to Sio per dozen; extra, Siz.to Sis per dozen. Very low prices per I, ooo.

APRICOTS. For fruit houses and outside planting at reasonable rates.

FIGS. Best varieties, well furnished and well rooted plants, 50 cts. each: extra, SI. Imported Smyrna varieties at special low rates per I,ooo. Prices and particulars on application.

OLIVES. Well rooted young trees or cuttings, per IOo or I, OOO at reasonable prices.

BEST HARDY GRAPES. Full assortment of leading kinds. Strong vines for early bearing, 25 to $50 \mathrm{cts} ; \$ 1.00$ per dozen. Low rates in quantity.
BLACK GRAPES, Champion, Concord, Creve= ling, Eaton, Eumelan, Hartford, Mills, et:.

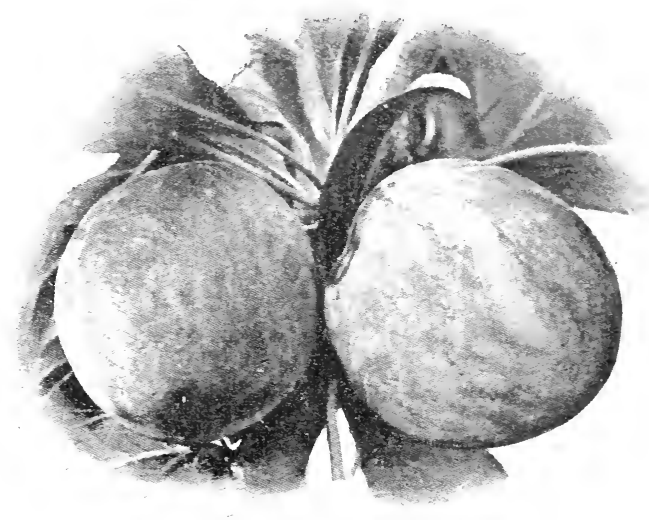

BURBAX゙K PLUMS

RED GRAPES, Agawam, Brighton, Catawba, Delaware, Gærtner, Iona, Meyer, Pough= keepsie Red, Rochester, Salem, Ulster, Prolific.

WHITE GRAPES, Green Mountain, Empire State, Diamond, Duchess, Hayes, Geneva, Jessica. Lady Washington, Martha, Niagara, Pocklington, Prentiss, Rebecca, Winchell.

\section{FOREIGN VINES FOR GRAPERIES.}

For obtaining satisfactory results in vineries, the importance of obtaining vigorous, healthy, well rooted and properly grown vines should not be overlooked, whether for planting or extra fruiting size for immediate bearing. My fine imported English-grown rines are unsurpassed, and invariably gire satisfaction.

Leading kinds for both hot and cold graperies, SI.50 each; SI 5 per dozen. Selected and extra, S2 and $\$ 2.50$ each. Extra fruiting vines, the best obtainable, \$5 each; $\$ 50$ per dozen. Orders for these Foreign Vines should be sent as early as possible. C. G. for Cold Grapery; H. G. for Hot Grapery. BLACK or PURPLE VARIETIES. Barbarosa (H. G.), Black Froxtigatis (H. G.), Black Haiburg

(H. or C. G.), Gros Colmax (H. or C. G.), Lady Downs (C. H. G), Muscat, Hamburg (H. or C. G.,

RED VARIETIES. Frontigaia (C. G.), Red Chasselas (C. G.)

WHite VARIETIES. Bucklayd Sweetwater (C. G.), Caxion Hall Muscat (H. G.), Deke of

Buccleuch (H. G.), Foster's Seedlixg (C. G.), Goldex Champios (H. G.), Goldex Hamblrg (C. G.), Muscat of Alexandria (H. G.), Royal Muscadine (C. G.), Syriax (H. G.), and others.

See also Catalogue No. 50 for I903.

\section{Small Fruits.}

Very fine stock of the following, the best of the Small Fruits, at very low prices.

Many other varieties as described in Catalogue Nio. 5o, can be supplied, of excellent quality at lowest rates.

BLACKBERRIES, Ancient Briton, Agawam, Dorchester, Early King. Eldorado, Erie, Lawton, Kittatiny, Thornless, -Snyder, Tay= lor, Wilson's Iceberg. New rariety white berries and others, 50 cts. to \$I per dozen. Low rates in quantity.

DEWBERRY. Trailing Blackberry. Ripens before other blackberries. 
CURRANTS. Fay's Prolific. Largest and best red currants. Black English, Champion, Cherry, North Star, Versailles, Victoria, Prince Albert, Red Dutch, White Grape Wilder. New red currant; fine. Selected two or three year plants. \$I to \$2 per dozen. Low rates per Ioo and $\mathrm{I}$, ooo.

GOOSEBERRY. Columbus. New, of largest size and finest quality Very productive; fine.

GOOSEBERRY. America, Downing, Houghton, Red Jacket, Smith's, etc. \$I per dozen. Low rates per I, ooo.

GOOSEBERRY, Crown Bob, White, Smith's Improved, etc. Best English varieties. \$2.50 per dozen.

GOOSEBERRY, Industry. Extra large and fine. \$I.50 per dozen. Special prices per I,ooo.

LOGAN BERRY. A new hybrid or cross between a Blackberry and Raspberry. Fruit similar in form and size to Blackberry, dark red color. Raspberry flavor. A desirable nowelty. $\$ 3$ and $\$+$ per dozen.

MAYBERRY, Japanese Golden. Golden berries; early in May; large fruit. \$4 per dozen.

RASPBERRIES. CHAMPLAIN, very hardy, large, and one of the best yellow raspberries; ColumBIAN, very large, hardy, enormously productive, one of the best red varieties; CLARKE,
Fastolf, Fontenay, Franconia, Herstine, Brinkle's Orange; Superlative, the best foreign red: Golden Queen, Cuthbert, Eureka Gregg, Kansas Louden, Marlboro, very fine red; Miller, new early red; Ohio, Shaffer's Colossal.

The above and other desirable varieties, 50 cts. to $\$ I$ per dozen. Low rates per Ioo and I,OOO.

STRAWBERRIES. To ensure a good crop the following season, POT PLANTS SHOULD BE PUT OUT IN ADVANCE. These are in every way preferable to layer plants, and are now generally used for garden planting as for forcing. There is little or no risk in transplanting these pot-grown plants, and the early fruiting makes them most desirable and in general demand.

STRAWBERRIES, Best Early Varieties. Gladstone, very large and early; Excelsior, Michael's Early, Parker Early, Beder Wood, HAVERLAND.

STRA WBERRIES, Best $M$ id=Season Varieties. Bubach, Sharpless, Wir. Belt, McKinkey, Nick OHMER.

STRAWBERRIES, Late Varieties. BRANDYWine, large, fine quality; Downing, Marshall, Michigan. Fine, pot-grown plants, $\$ 3$ to $\$ 5$ per IOo; layer plants, \$I to $\$ 2$ per 100 .

\section{Esculent Roots.}

\section{ASPARAGUS.}

Very fine, 2 and 3 years, $\$ 2$ per Ioo; \$10 to \$15 per I,00o. Extra Size, for Forcing, \$3 to \$5 per ioo. Best kinds: Conover's Colossal, Mammoth, MIoore's Crossbred, Palmetto.

\section{RHUBARB.}

Fine strong roots of best varieties, \$2 per dozen; low rates per ioo. Brabant, Colossal, Early Crimsox, Early Scarlet, Giant Victoria, $\leq$ tc.

\section{Lawn Grass Seed.}

The seed here quoted may be relied upon as being of the highest grade, and to give satisfaction. For New Lawn, + to 6 bushels per acre. Renovating Old Lawns, I to 2 bushels per acre. Price, extra choice LaWN Seed, the very best, \$4.50 per bushel, i5 lbs.

Choice Lawn Grass Seeds, first quality, "Central Park Mixture," \$3.50 per bushel, i5 lbs. SPECIAL qUOTATIONS FOR LARGE QUANTITIES UPON APPLICATION.

For further particulars see General Catalogue No. 50 for 1903.

You are an old acquaintance of mine in the sense that more than twenty years ago you furnished trees and shrubs to Mt. Hope, which are to-day an ornament to the grounds and an evidence of your good judgment in the recommending of new and rare introducticns.

Mattapan, Mass.

J. H. M. 


\section{A FEW SPECIALTIES}

\section{Fine Stock at Very Low Prices. Autumn 1903.}

ALTHEA-Double flowering; $2 \mathrm{I} / 2$ to 3 feet.

AZALEA AMOENA--I2 to I 8 inches diameter.

AZALEA MOLLIS-All sizes, and extra specimens with 60 to 75 buds.

AZALEA VISCOSA-and other fine native varieties.

ARALIA PENTAPHYLLA $-21 / 2$ to 3 feet.

AMERICAN LINDEN- $2 \frac{1}{2}$ to 3 inch and 3 to 4 inch caliper.

ACER PLATANOIDES -Norway Maples; Io to 12 feet and $2 \frac{1}{2}$ to 3 inch caliper.

ACER JAPONICUM ATROPURPUREUM-From pots; I 8 to 24 inches.

ACER GINALE-S to Io feet.

AMERICAN ELM - Io to I2 feet.

BERBERRY THUNBERGII-I to 3 feet.

AMPELOPSIS QUINQUEFOLIA-2 and 3 years.

AKEBIA QUINATA-Strong vines.

EUONYMUS RADICANS.

LONICERA HALLEANA-and other leading kinds; strong vines; per I,000.

BAY TREES-Standards and Pyramids. Fine specimens.

CALIFORNIA PRIVET-All sizes; per I,000.

GOLDEN PRIVET-New and very fine.

CYDONIA, Japan Quince--IS inches to 3 feet.

DWARF BOX-For edging; per I,000 and Io,000.

ILEX CRENATA-Io to 20 inches.

HYDRANGEA, Paniculata Grandiflora-All sizes, I to 4 feet; per $I, 000$.

SPIREA WATERI -2 to $21 / 2$ feet.

SYMPHORICARPUS VULGARIS-2 to 4 feet.

SAMBUCUS, Plumosa Aurea-A fine stock of this new and beautiful hardy shrub.

ROSA RUGOSA-- Bushy fine plants; per I,000.

TECOMA RADICANS-Strong plants.

RHODODENDRONS-The largest and finest stock of the strictly hardy named and seedling Rhododendrons obtainable in this country or in Europe. See pages 30 to 32 of Catalogue No. 50 and special circular.

RHODODENDRON MAXIMUM-Extra fine plants of all sizes up to Grand Specimens 5 and 6 feet. In carload lots as described in catalogues and Rhododendron circular.

KALMIA LATIFOLIA-All sizes. Extra fine piants.

TREES FOR FORMAL GARDENS-Grand Trained Specimen Evergreens. Thousands of Box, Yews, Piceas, Retinosporas, etc., removed with ball and exceptionally good stock.

TRAINED FRUIT TREES AND FOREIGN GRAPE VINES-Very fine stock in large variety and sizes as described in catalogues.

Send for prices on above and other stock wanted and thus secure the best material and lowest prices.

\section{FREDERICK W. KELSEY,}






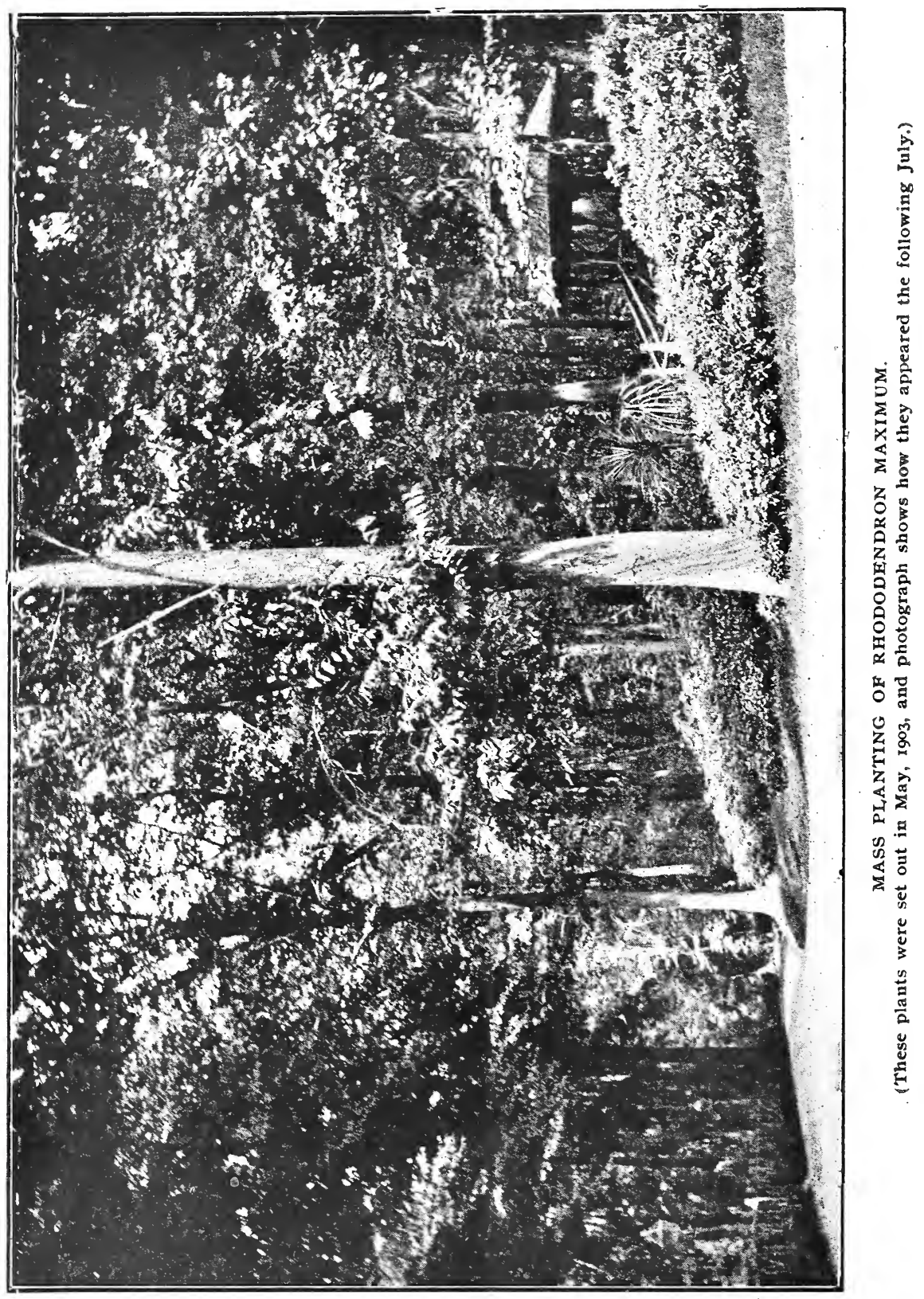

